\title{
ПОЛНОМОЧИЯ НАЛОГОВЫХ ОРГАНОВ ПРИ ПРИМЕНЕНИИ ОТВЕТСТВЕННОСТИ ЗА НАЛОГОВЫЕ ПРЕСТУПЛЕНИЯ
}

\section{Введение в проблему}

$\mathrm{B}$ Российской Федерации функции контроля и надзора за соблюдением налогоплательщиками и налоговыми агентами законодательства о налогах и сборах, а также за правильностью исчисления, полнотой и своевременностью внесения обязательных платежей в бюджетную систему, возложены на налоговые органы ${ }^{1}$. Они представляют собой единую централизованную систему, состоящую из федерального органа исполнительной власти, уполномоченного по контролю и надзору в области налогов и сборов (ФНС России), и его территориальных органов.

В рамках осуществления своей деятельности налоговые органы являются участниками не только налоговых, но и административных правоотношений. Деятельность налоговых органов не обходится без взаимодействия с органами исполнительной власти (Минфином РФ и др.), судебной власти, правоохранительными органами, другими налоговыми органами, в том числе с компетентными органами иностранных государств. Порядок и форма такого взаимодействия установлены и регламентируются законодательством о налогах и сборах, нормативными правовыми актами органов исполнительной власти ${ }^{2}$, на-

1 См., в частности: Корнева Е.А., Ткачев В.Н. Правовое регулирование полномочий налоговых органов: комментарий законодательства для налоговика и налогоплательщика. - М.: Городец, 2007. - 352 с.; Топоров А.В. Полномочия налоговых органов по обеспечению поступлений налоговых платежей в бюджетную систему // Вестник Саратовской государственной академии права. - Саратов: Изд-во СГАП, 2011. - № 1 (77). - С. 164-166.

2 Постановление Правительства РФ от 30 сентября 2004 г. № 506 «Об утверждении Положения о Федеральной налоговой службе» // С3 РФ. - 2004. - № 40. - Ст. 3961; Приказ Минфина России от 9 августа 2005 г. № 101н «Об утверждении Положений о территориальных органах Федеральной ходят разъяснение и толкование в ведомственных (локальных) актах.

Одним из полномочий налоговых органов по взаимодействию с правоохранительными органами является направление в следственные органы материалов налоговой проверки для решения вопроса о возбуждении уголовного дела. Данные действия налоговые органы обязаны осуществить в случае, если налогоплательщик (налоговый агент) не уплатил (не перечислил) недоимку, размер которой позволяет налоговому органу предполагать факт совершения нарушения законодательства о налогах и сборах, содержащего признаки преступления.

До недавнего времени уголовное дело за налоговые преступления могло быть возбуждено правоохранительными органами как на основании материалов, направленных налоговыми органами, так и по результатам инициирования самостоятельной проверки, в том числе на основании сообщения о совершенном налоговом преступлении. Однако, в свете проводимой в государстве модернизации уголовного законодательства в сфере экономических преступлений, а также в связи с возникшей потребностью в установлении дополнительных гарантий соблюдения прав и законных интересов налогоплательщиков и налоговых агентов, в ряд нормативных правовых актов законодателем были внесены существенные изменения.

Так, в соответствии с ч. 1.1 ст. 140 УПК РФ (введена Федеральным законом от 6 декабря 2011 г. № 407-Ф3 и действует с 7 декабря 2011 г.) единственным основанием для возбуждения уголовного дела о преступлениях,

налоговой службы» // Бюллетень нормативных актов федеральных органов исполнительной власти. -2005 . - № 38 . 
предусмотренных ст. 198-199.2 УК РФ, служат только те материалы, которые направлены налоговыми органами в соответствии с законодательством о налогах и сборах для решения вопроса о возбуждении уголовного дела. В соответствии с п. 3 ст. 108 НК РФ основанием для привлечения лица к ответственности за нарушение законодательства о налогах и сборах является установление факта совершения данного нарушения решением налогового органа, вступившим в силу.

Таким образом, налоговый орган является субъектом, по сути, определяющим судьбу уголовного преследования за налоговые преступления. Именно от дальнейших действий налогового органа после проведения проверки и вынесения по ее результатам решения зависит факт того, будут налогоплательщики и налоговые агенты привлечены к уголовной ответственности или нет ${ }^{3}$.

В настоящее время указанные законодательные изменения привели к значительному сокращению уголовных дел о преступлениях, предусмотренных ст. 198-199.2 УК РФ. Однако, представляется, что не стоит ожидать от налоговых органов активных действий и роста выявляемых налоговых преступлений. Если раньше из всего количества налоговых преступлений всего 8\% выявлялось налоговыми органами, а подавляющее большинство - около 85\% - выявлялось органами внутренних дел, то сейчас показатели выявления налоговыми органами налоговых преступлений останутся примерно на том же уровне.

Справедливо замечание на этот счет Г. Смирнова, по мнению которого причиной столь низкой раскрываемости налоговыми органами соответствующих преступлений является не то, что они не умеют выявлять их, а исключительно то обстоятельство, что для них задача противодействия налоговой преступности - лишь сопутствующая. В связи с этим налоговые органы не имеют полномочий по осуществлению оперативно-розыскной деятельности, по результатам которой в основном и выявляются преступления, включая сложные преступные схемы уклонения от уплаты налогов. Г. Смирнов делает вывод, что полная передача функции выявления налоговых преступлений налоговым органам при условии, что их полномочия и правила проведения налоговых проверок останутся прежними, может привести к

\footnotetext{
3 См., в частности: Шишко А.В. Проблемы, вызванные особой ролью решения налогового органа, при возбуждении уголовных дел о налоговых преступлениях // Таможенное взаимодействие, экономические связи и правовое регулирование в Азиатско-Тихоокеанском регионе и Таможенном союзе: сборник материалов международной научной конференции. - Владивосток: РИО Владивосток. филиала Российской таможенной академии, 2012. - С. 332-340.
}

сокращению числа выявленных преступлений в налоговой сфере еще на $92 \%{ }^{4}$.

Порядок, основания и сроки направления материалов налоговых проверок в следственные органы установлены п. 3 ст. 32 НК РФ. В состав передаваемых налоговыми органами материалов входит решение о привлечении к ответственности за совершение налогового правонарушения, письменные возражения налогоплательщика (налогового агента), акт налоговой проверки, документы, подтверждающие факты нарушений законодательства о налогах и сборах, выявленные в ходе проверки. Следует обратить внимание на случаи низкого качества подготовки таких материалов и их различные недостатки, что позволяет защите налогоплательщика (налогового агента) развалить в суде уголовное дело либо вовсе не довести ситуацию до его возбуждения. Основная причина этому - недостаточность собранных в ходе налоговой проверки сведений и документов, ненадлежащее оформление и описание в акте проверки и решении собранных сведений и документов (объективной стороны преступления). Зачастую сотрудники налоговых органов не уделяют должного внимания фиксированию и сохранению следов совершенных налоговых преступлений, документированию умысла на совершение уклонения от уплаты налогов и неисполнения обязанностей налогового агента. Кроме того, у налоговых и следственных органов различные методы выявления налоговых преступлений: у первых они контрольные, которые применяются в отношении представляемых в ходе налоговой проверки деклараций и документов, проведение допросов свидетелей, у вторых - оперативно-розыскные, которые позволяют сочетать гласные и негласные формы работы.

Таким образом, важным фактором, влияющим на поведение налогоплательщиков (налоговых агентов) по надлежащему исполнению своих налоговых обязанностей, а, стало быть, и на число раскрываемых налоговых преступлений, является эффективный порядок взаимодействия налоговых и следственных органов. В первую очередь это вопрос качества проводимых налоговыми органами налоговых проверок, качества собранных ими материалов, содержащих информацию о признаках налогового преступления.

Поскольку в большинстве своем сотрудники следственных органов обладают меньшей квалификацией и незначительными познаниями в сфере налогообложения, то дальнейшее раскрытие преступления и квалификация деяния, как уголовно наказуемого по ст. 198-199.2

\footnotetext{
4 См.: Смирнов Г. Пороки радикальной либерализации уголовной политики в сфере налогообложения // Портал Право. py. URL: http://pravo.ru/review/face/view/62345/ (дата обращения: 11.10.2013).
} 
УК РФ, в значительной степени зависит от качества материалов, направленных налоговыми органами.

Пунктом 3 ст. 32 НК РФ установлено, что если в течение двух месяцев со дня истечения срока исполнения требования об уплате налога, направленного налогоплательщику (налоговому агенту) на основании решения о привлечении к ответственности за совершение налогового правонарушения, налогоплательщик (налоговый агент) не уплатил (не перечислил) в полном объеме указанные в данном требовании суммы недоимки, размер которой позволяет предполагать факт совершения нарушения законодательства о налогах и сборах, содержащего признаки преступления, соответствующих пеней и штрафов, налоговые органы обязаны в течение 10 дней со дня выявления указанных обстоятельств направить материалы в следственные органы, уполномоченные производить предварительное следствие по уголовным делам о преступлениях, предусмотренных ст. 198-199.2 УК РФ, для решения вопроса о возбуждении уголовного дела.

Из указанной нормы следует, что обязанность налогового органа по направлению соответствующих материалов в следственные органы поставлена в зависимость от следующих условий:

- имеется вступившее в силу решение о привлечении налогоплательщика (налогового агента) к ответственности за совершение налогового правонарушения, на основании которого направляется требование об уплате налога;

вершения нарушения законодательства о налогах и сборах, содержащего признаки преступления;

- налогоплательщик (налоговый агент) не уплатил (не перечислил) в полном объеме указанные в данном требовании суммы недоимки;

- прошло два месяца со дня истечения срока исполнения требования об уплате налога (сбора).

Из последнего критерия (основания), при наличии которого налоговый орган должен исполнить обязанность по направлению материалов в следственные органы, усматривается, что необходимым условием является факт истечения срока, в течение которого налогоплательщик может уплатить сумму недоимки, в результате чего собранные в отношении него материалы не будут направлены в органы следствия.

Следовательно, указанный срок (срок для добровольного исполнения + 2 месяца) является значимым для определения оснований исполнения налоговым органом обязанности, предусмотренной п. 3 ст. 32 НК РФ.

\section{Содержание проблемы}

Обязан ли налоговый орган направить материалы в следственные органы в порядке п. 3 ст. 32 НК РФ, если суд приостановил исполнение решения налогового органа и соответствующего требования об уплате недоимки?

Данная проблема возникает в ситуации, когда решение о привлечении к ответственности за совершение налогового правонарушения и требование об уплате недоимки оспорены налогоплательщиком (налоговым агентом) в судебном порядке, и суд вынес определение о приостановлении действия указанного решения и требования до вступления в законную силу судебного акта по делу. Решение данного вопроса имеет важное практическое значение.

Казалось бы, с одной стороны, один лишь только факт направления материалов проверки в следственные органы в период действия обеспечительных мер должен являться основанием для признания судом действий налогового органа незаконными по формальным основаниям (без доказывания налогоплательщиком (налоговым агентом) негативных последствий и ущерба от действий налогового органа). Вместе с тем, с другой стороны, ст. 198 АПК РФ предусматривает следующее: «граждане, организации и иные лица вправе обратиться в арбитражный суд с заявлением о признании недействительными ненормативных правовых актов, незаконными решений и действий (бездействия) органов, осуществляющих публичные полномочия, должностных лиц, если полагают, что оспариваемый ненормативный правовой акт, решение и действие (бездействие) не соответствуют закону или иному нормативному правовому акту и нарушают их права и законные интересы в срере предпринимательской и иной экономической деятельности, незаконно возлагают на них какие-либо обязанности, создают иные препятствия для осуществления предпринимательской и иной экономической деятельности» (курсив автора - А.Н.). Исходя из этой позиции и буквального толкования указанной нормы, при оспаривании действий налоговых органов по передаче материалов проверки в следственные органы необходимо установить не только факт принятия к тому моменту обеспечительных мер, но и доказать нарушение прав и интересов налогоплательщика (налогового агента) от неправомерных действий налогового органа (материальный состав).

Для более полного уяснения данной проблемы обратимся к разъяснениям налоговых органов и судебной практике по арбитражным делам.

Минфин России в письме от 1 июля 2013 г. № 0302-08/250395 разъяснил, что НК РФ не предусматривает особенности направления материалов проверок в

\footnotetext{
СПС «КонсультантПлюс».
} 
следственные органы в случаях принятия судом обеспечительных мер, а также не предусматривает продление течения срока направления налоговыми органами в следственные органы таких материалов для решения вопроса о возбуждении уголовного дела.

ФНС России в письмах от 29 декабря 2011 г. № AC-4-2/225006, от 11 октября 2011 г. № AC-4-2/167957 также разъяснила, что наличие определения суда о принятии обеспечительных мер не препятствует направлению материалов проверки в следственные органы на основании п. 3 ст. 32 НК РФ. Такая обязанность налоговых органов не зависит от принятия судами обеспечительных мер.

\section{Правовые позиции налогового органаё}

\section{и налогового агента}

В одном из арбитражных дел ${ }^{8}$ налоговый орган ссылался на то, что, направляя в следственные органы материалы проверки, он полагал необходимым проверку на наличие в действиях должностных лиц налогоплательщика (налогового агента) признаков преступления, необходимости возбуждения уголовного дела. Налоговый орган указывал, что направление материалов проверки в следственные органы само по себе не нарушает прав и законных интересов налогоплательщика (налогового агента), поскольку не предрешает выводы следственных органов относительно вопроса о возбуждении уголовного дела и не возлагает на налогоплательщика (налогового агента) какихлибо обязанностей.

Доводы общества о том, что по материалам, направленным налоговым органом, ведется проверка, проводятся следственные действия, вызываются работники общества для дачи объяснений с отрывом от производственной деятельности, обследуются помещения, что ведет к нарушению нормального режима деятельности общества, негативно влияет на деловую репутацию, были отклонены налоговым органом, как не имеющие основание для выводов, что этими действиями нарушаются права и интересы общества именно налоговым органом. Налоговый орган указывал, что приведенные обществом обстоятельства могут явиться основанием для обжалования действий следственных, но не налоговых органов.

\section{6 СПС «КонсультантПлюс».}

7 СПС «КонсультантПлюс».

8 Решение Арбитражного суда г. Москвы от 24 сентября 2013 г. по делу № A40-97820/13 // Официальный сайт Высшего Арбитражного Суда РФ // URL: http://kad.arbitr. ru/PdfDocument/dbcc223f-2bcb-42d1-a93d-fe18fa9c7ffc/A4097820-2013_20130924_Reshenija\%20i\%20postanovlenija.pdf (дата обращения: 11.10.2013).
По данному делу Арбитражный суд г. Москвы признал незаконными действия налогового органа по передаче материалов проверки в следственные органы и обязал налоговый орган устранить допущенные нарушения прав и законных интересов общества посредством отзыва материалов проверки из следственных органов.

Рассмотрим доводы и аргументацию, которыми руководствовался суд.

Положениями АПК РФ предусмотрена возможность приостановления действия оспариваемых ненормативных правовых актов, запрет осуществлять какие-либо действия, основанные на таких актах индивидуального правового регулирования (принятие обеспечительных мер в соответствии со ст. 91 АПК РФ).

В п. 29 Постановления Пленума Высшего Арбитражного Суда РФ от 12 октября 2006 г. № 55 «О применении арбитражными судами обеспечительных мер ${ }^{9}$ разъяснено, что при обжаловании решений налоговых органов арбитражный суд приостанавливает (если имеется соответствующее ходатайство) исполнение оспариваемого решения до вынесения судебного акта. Приостановление акта, решения государственного или иного органа, должностного лица не влечет их недействительности. Под приостановлением действия ненормативного правового акта, решения, согласно ч. 3 ст. 199 АПК РФ, в качестве обеспечительной меры понимается запрет исполнения действий, предусмотренных данным актом, решением.

Пунктом 9 этого же Постановления ВАС РФ установлено, что обеспечительные меры могут быть направлены на сохранение существующего состояния отношений (status quo) между сторонами.

Согласно п. 4 Информационного письма Президиума Высшего Арбитражного Суда РФ от 13 августа 2004 г. № 83 «О некоторых вопросах, связанных с применением ч. 3 ст. 199 АПК РФ» ${ }^{10}$ под приостановлением действия ненормативного правового акта, решения понимается запрет исполнения тех мероприятий, которые предусматриваются данным актом, решением.

Таким образом, приостановление действия ненормативных правовых актов, в том числе решения о привлечении к ответственности за совершение налогового правонарушения, требования об уплате недоимки, приостанавливает течение сроков, наличие которых связано с самим фактом существования соответствующих ненормативных правовых актов.

Приостановление судом действия решения налогового органа также означает, что на период действия

\footnotetext{
9 Вестник ВАС РФ. - 2006. - № 12.

10 Вестник ВАС РФ. - 2004. - № 10.
} 
обеспечительных мер приостанавливается установленная в требовании обязанность по уплате недоимки, а налогоплательщик на основании закона имеет возможность не платить по требованию налогового органа до отмены мер по обеспечению иска.

Следовательно, до окончания действия обеспечительных мер налоговый орган не может констатировать факт неисполнения налогоплательщиком обязанности по уплате налога (налогоплательщик (налоговый агент) не может считаться не уплатившим указанные в требовании суммы).

В данном случае рассматриваемые положения НК РФ и АПК РФ должны применяться в своей системной совокупности, что означает приостановление течения срока, при наступлении которого налоговый орган обязан направить в следственные органы материалы проверки для решения вопроса о возбуждении уголовного дела.

В противном случае возникает коллизия, при которой налогоплательщик (налоговый агент) имеет право не уплачивать недоимку по требованию налогового органа, в то время как налоговый орган, руководствуясь исключительно положениями НК РФ, констатирует факт неисполнения налогоплательщиком (налоговым агентом) обязанности по погашению требования и направляет материалы в следственные органы.

При этом суд отклонил доводы налогового органа о том, что налоговым законодательством не предусмотрена возможность продления срока направления налоговыми органами материалов проверки в следственные органы. Нормы налогового и процессуального законодательства должны применяться в совокупности. Нет оснований руководствоваться позицией налогового органа о том, что НК РФ не делает никаких исключений для исполнения рассматриваемой обязанности при наличии или отсутствии мер по обеспечению иска, поскольку ст. 46, 47 НК РФ также не содержат каких-либо норм о приостановлении течения сроков на период действия принимаемых арбитражными судами обеспечительных мер. Однако принятие судом обеспечительных мер приостанавливает течение сроков на принудительное взыскание, установленное указанными статьями НК РФ. Такой вывод подтверждается п. 76 Постановления Пленума Высшего Арбитражного суда РФ от 30 июля 2013 г. № 57 «О некоторых вопросах, возникающих при применении арбитражными судами части первой Налогового кодекса Российской Федерации» ${ }^{11}$.

Таким образом, принятие судом в установленном порядке обеспечительных мер в виде приостановления действия ненормативного правового акта исключает

11 Документ опубликован не был. СПС «КонсультантПлюс». возможность совершения налоговым органом любых действий, направленных на взыскание налогов, пени и штрафов, а также означает запрет совершения любых иных действий, основанных на оспариваемом акте.

В соответствии с ч. 1 ст. 16 АПК РФ вступившие в законную силу судебные акты арбитражного суда являются обязательными для органов государственной власти, органов местного самоуправления, иных органов, организаций, должностных лиц и граждан и подлежат исполнению на всей территории РФ. При этом согласно ч. 1 ст. 96 АПК РФ определение арбитражного суда об обеспечении иска приводится в исполнение немедленно в порядке, установленном для исполнения судебных актов арбитражного суда.

Аналогичные выводы подтверждаются сложившейся судебной практикой, в соответствии с которой действия налоговых органов по направлению материалов налоговой проверки в следственные органы в период действия обеспечительных мер признаются незаконными (Постановления ФАС Поволжского округа от 6 августа 2013 г. по делу № A12-31578/12 12 , от 10 июля 2013 г. по делу № A57-22703/2012 ${ }^{13}$, ФАС Уральского округа от 1 октября 2012 г. по делу № A71-10637/11 ${ }^{14}$, ФАС Московского округа от 29 апреля 2011 г. по делу № A40-92492/10-112-47915, Постановления 17AAC от 8 августа 2011 г. по делу № A71-4937/2011' бря 2012 г. по делу № A50-11402/2012 ${ }^{17}$ и др.).

Что касается проблемы квалификации совершенного налоговым органом правонарушения с точки зрения необходимости наступления вреда, то данный вопрос является дискуссионным. Представляется правильным, что в период действия обеспечительных мер налоговый орган не имеет оснований для направления материалов проверки в следственные органы. Принятие обеспечительных мер в виде приостановления действия ненормативного правового акта исключает возможность совершения налоговым органом любых действий, направленных на взыскание налогов, пени и штрафов, а также означает запрет совершения любых иных действий, основанных на оспариваемом акте. Наличие данного запрета является достаточным для признания судом незаконными действий налогового органа.

Вместе с тем, анализ судебной практики показал наличие противоположной точки зрения. Так, ФАС За-

\footnotetext{
12 СПС «КонсультантПлюс».

13 СПС «КонсультантПлюс».

14 СПС «КонсультантПлюс».

15 СПС «КонсультантПлюс».

16 СПС «КонсультантПлюс».

17 СПС «КонсультантПлюс».
} 
падно-Сибирского округа в постановлении от 2 июля 2013 г. по делу № A46-30437/2012 ${ }^{18}$ хоть и согласился с выводами нижестоящих судов, что налоговый орган направил материалы проверки в следственные органы в период действия обеспечительных мер, тем не менее, отменил судебные акты первой и апелляционной инстанций. Отказывая в удовлетворении требований налогоплательщика (налогового агента), суд кассационной инстанции указал, что общество не доказало реального нарушения оспариваемыми действиями налогового органа своих прав и законных интересов в сфере предпринимательской деятельности.

Рассмотрим доводы и аргументацию, которыми руководствовался суд кассационной инстанции.

Согласно ч. 1 ст. 198 АПК РФ налогоплательщики (налоговые агенты) вправе обратиться в арбитражный суд с заявлением о признании незаконными действий налоговых органов, если полагают, что действия не соответствуют закону или иному нормативному правовому акту и нарушают их права и законные интересы в сфере предпринимательской и иной экономической деятельности, незаконно возлагают на них какие-либо обязанности, создают иные препятствия для осуществления предпринимательской и иной экономической деятельности.

При рассмотрении дел об оспаривании действий государственных органов арбитражный суд осуществляет проверку оспариваемых действий и устанавливает их соответствие закону или иному нормативному правовому акту, устанавливает наличие полномочий у органа, который совершил оспариваемые действия, а также устанавливает, нарушают ли эти действия права и законные интересы заявителя в сфере предпринимательской и иной экономической деятельности (ст. 200 АПК РФ).

Как разъяснено в п. 6 совместного Постановления Пленума Верховного Суда РФ № 6, Пленума Высшего Арбитражного Суда РФ № 8 от 1 июля1996 г. «О некоторых вопросах, связанных с применением части первой Гражданского кодекса Российской Федерации ${ }^{19}$ основанием для принятия решения суда о признании ненормативного акта, а в случаях, предусмотренных законом, также нормативного акта государственного органа или органа местного самоуправления недействительным, являются одновременно как его несоответствие закону или иному правовому акту, так и нарушение указанным актом гражданских прав и охраняемых законом интересов гражданина или юридического лица, обратившихся в суд с соответствующим требованием.

При этом ФАС Западно-Сибирского округа указал, что для признания в судебном порядке ненормативного акта

\footnotetext{
18 СПС «КонсультантПлюс».

19 Вестник ВАС РФ. - 1996. - № 9.
}

налогового органа недействительным (действий, бездействия - незаконными) необходимым условием является доказательство налогоплательщиком (налоговым агентом) факта нарушения его конкретных (а не предполагаемых) прав и законных интересов в сфере предпринимательской (иной экономической) деятельности.

На этом основании суд кассационной инстанции пришел к выводу, что осуществление следственными органами действий в рамках предварительной проверки, предоставление следственным органам по их представлению материалов (документов) не свидетельствуют о том, что права общества как субъекта предпринимательской деятельности были нарушены, что возникли препятствия для осуществления им предпринимательской деятельности (например, при заключении и исполнении контрактов, получении лицензий и т.п.) $)^{20}$.

\section{Нарушение прав и законных интересов налогоплательщиков (налоговых агентов) в сфере предпринимательской (иной экономической) деятельности}

Рассмотрим конкретные примеры того, в чем конкретно может выражаться такое нарушение. Сюда можно отнести распространение в СМИ, сети Интернет сведений, порочащих деловую репутацию общества как налогоплательщика (налогового агента) ${ }^{21}$. Тем самым неопределенный круг лиц становится проинформированным о совершении налогоплательщиком (налоговым агентом) правонарушения в период рассмотрения спора судом и действия приостанавливающего решение налогового органа судебного акта (определения о принятии обеспечительных мер). При этом неопределенный круг лиц становится проинформированным о наличиях в действиях налогоплательщика (налогового агента) признаков преступления в виде уклонения от уплаты налогов (не перечисления налогов в бюджет). Информация о нарушении налогового законодательства порочит деловую репутацию общества, характеризуя его как недобросовестного налогоплательщика (налогового агента), уклоняющегося от исполнения возложенных на него обязанностей по уплате (перечислению) налогов.

В п. 1 Постановления Пленума Верховного Суда РФ от 24 февраля 2005 г. № 3 «О судебной практике по де-

\footnotetext{
20 На момент сдачи статьи в редакцию на сайте www.arbitr.ru отсутствовала информация о передаче или об отказе в передаче указанного дела для рассмотрения в Президиум ВАС РФ.

21 Решение Арбитражного суда г. Москвы от 24 сентября 2013 г. по делу № А40-97820/13 // Официальный сайт Высшего Арбитражного Суда РФ // URL: http://kad.arbitr. $\mathrm{ru} /$ PdfDocument/dbcc223f-2bcb-42d1-a93d-fe18fa9c7ffc/A4097820-2013_20130924_Reshenija\%20i\%20postanovlenija.pdf (дата обращения: 11.10.2013).
} 
лам о защите чести и достоинства граждан, а также деловой репутации граждан и юридических лиц» ${ }^{22}$ разъяснено, что деловая репутация юридических лиц - одно из условий их успешной деятельности. Порочащими, в частности, являются сведения, содержащие утверждения о нарушении гражданином или юридическим лицом действующего законодательства, неправильном, неэтичном поведении в личной, общественной или политической жизни, недобросовестности при осуществлении производственно-хозяйственной и предпринимательской деятельности.

Распространение сведений о том, что исполнительным органом организации совершено такое общественно-опасное деяние, как преступление, не может не отразиться на деловой репутации юридического лица. Могут быть признаны порочащими сведения о наличии у организации задолженности, доведенные до неопределенного круга лиц.

Таким образом, размещение информации в СМИ, сети Интернет для неопределенного круга лиц о том, что заявитель уклоняется от уплаты налогов умаляет (подрывает) деловую репутацию налогоплательщика (налогового агента) в сфере предпринимательской и иной экономической деятельности, свидетельствует о его недобросовестности при осуществлении предпринимательской деятельности, т.е. создает негативное впечатление о его деятельности и формирует отрицательное к нему отношение.

Кроме того, нарушение прав и законных интересов налогоплательщика (налогового агента) может заключаться в возложении на него дополнительных обязанностей и расходов. Сюда можно отнести то обстоятельство, что по материалам, направленным налоговым органом в следственные органы, ведется проверка, в ходе которой работники общества вызываются для дачи объяснений с отрывом от производственной деятельности, проводятся обыски, изымается документация. Кроме того, общество иногда вынуждено оплачивать расходы адвоката, участвующего при проведении допроса, поскольку допрос генерального директора затрагивает интересы общества.

\section{Библиографический список:}

1. Корнева Е.А., Ткачев В.Н. Правовое регулирование полномочий налоговых органов: комментарий законодательства для налоговика и налогоплательщика. - М.: Городец, 2007. - 352 с.

2. Смирнов Г. Пороки радикальной либерализации уголовной политики в сфере налогообложения // Портал Право.ру.

3. Топоров А.В. Полномочия налоговых органов по обеспечению поступлений налоговых платежей в бюджетную систему // Вестник Саратовской государственной академии права. - Саратов: Изд-во СГАП, 2011. № 1 (77). - С. 164-166.

4. Шишко А.В. Проблемы, вызванные особой ролью решения налогового органа, при возбуждении уголовных дел о налоговых преступлениях // Таможенное взаимодействие, экономические связи и правовое регулирование в Азиатско-Тихоокеанском регионе и Таможенном союзе: сборник материалов международной научной конференции. - Владивосток: РИО Владивосток. филиала Российской таможенной академии, 2012. C. 332-340.

\section{References (transliteration):}

1. Korneva E.A., Tkachev V.N. Pravovoe regulirovanie polnomochii nalogovykh organov: kommentarii zakonodatel'stva dlya nalogovika i nalogoplatel'shchika. - M.: Gorodets, 2007. - 352 c.

2. Smirnov G. Poroki radikal'noi liberalizatsii ugolovnoi politiki v sfere nalogooblozheniya // Portal Pravo.ru.

3. Toporov A.V. Polnomochiya nalogovykh organov po obespecheniyu postuplenii nalogovykh platezhei $v$ byudzhetnuyu sistemu // Vestnik Saratovskoi gosudarstvennoi akademii prava. — Saratov: Izd-vo SGAP, 2011. — № 1 (77). — S. 164-166.

4. Shishko A.V. Problemy, vyzvannye osoboi rol'yu resheniya nalogovogo organa, pri vozbuzhdenii ugolovnykh del o nalogovykh prestupleniyakh // Tamozhennoe vzaimodeistvie, ekonomicheskie svyazi i pravovoe regulirovanie v Aziatsko-Tikhookeanskom regione i Tamozhennom soyuze: sbornik materialov mezhdunarodnoi nauchnoi konferentsii. Vladivostok: RIO Vladivostok. filiala Rossiiskoi tamozhennoi akademii, 2012. - S. 332-340.

22 Бюллетень Верховного Суда РФ. - 2005. - № 4. 